\title{
TOWARDS THE LEXICOGRAPHIC DESCRIPTION OF THE GRAMMATICAL BeHAVIOUR OF JAPANESE LoANWORDS: A CASE STUdY
}

\author{
Toshinobu MOGI \\ Naruto University of Education \\ tmogi@naruto-u.ac.jp
}

\begin{abstract}
The present papers offers a case study of a Japanese loanword verb, with the aim of contributing to corpus-based research on Japanese loanwords and of providing a foundation for the compilation of a dictionary of grammatical patterns of loanwords for learners of Japanese as a foreign language. The case study presents an analysis of actual usage of loanword suru-verbs in the large-scale Balanced Corpus of Contemporary Written Japanese, which is followed by a detailed analysis of all examples of the polysemous verb katto-suru. It is thereby shown how corpora can help in describing loanwords by matching a word's meaning with its patterns of usage, and how such a description can be useful to learners of Japanese as a foreign language.
\end{abstract}

\section{Keywords}

loanwords; gairaigo; corpus linguistics; sentence pattern; Japanese language teaching

\section{Izvleček}

Pričujoči članek predstavlja študijo primera japonskega glagola tujega izvora, z namenom prispevati h korpusno-osnovanim raziskavam japonskih tujk in obenem predlagati osnovne smernice za sestavo slovarja slovničnih vzorcev japonskih tujk za učence japonščine kot tujega jezika. Predstavljena je analiza rabe samostalniških glagolov na -suru v velikem uravnoteženem korpusu sodobne pisne japonščine (BCCWJ), čemur sledi podrobna analiza vseh primerov večpomenskega glagola katto-suru. S tem je prikazano, kako lahko uporaba korpusa pripomore $\mathrm{k}$ opisu tujk $\mathrm{z}$ vzporejanjem podpomenov in vzorcev rabe posameznih besed ter kako lahko tak opis koristi učencem japonščine kot tujega jezika.

\section{Ključne besede}

tujke; gairaigo; korpusno jezikoslovje; stavčni vzorec; učenje japonščine 


\section{Introduction}

The case study presented in this paper is a corpus-based contribution to Japanese loanword research which aims at preparing the conceptual framework for the compilation of a dictionary of grammatical patterns for learners of Japanese.

Section 2 reviews problems raised in previous linguistic and pedagogical research on loanwords, highlighting the need for research on Japanese loanwords which takes into account their grammatical behaviour. The following sections present a case study of nominal verbs (suru verbs) of foreign origin. Section 3 gives an account of the use of nominal verbs of foreign origin in a very large corpus of contemporary written Japanese, while section 4 offers an analysis of a polysemous verb, katto-suru, based on corpus examples. We thereby show how a corpus-based detailed description of a word, aligning the word's meanings with the word's syntactical behaviour, produces a description which is useful for learners of Japanese as a foreign language.

\section{On the need for research on the grammar of loanwords}

In Japanese lexicology, Japanese words are traditionally categorised according to their origin ( goshu 語種 in Japanese), i.e. according to how the word came to be used in Japanese. The lexicon of contemporary Japanese could be broadly divided into native words (koyügo 固有語) which existed originally in Japanese, and borrowed words (shakuyōgo 借用語) which were borrowed from other languages, but it is traditionally categorised further, making a three-fold distinction between domestic words (wago 和語), words borrowed from Chinese (kango 漢語) and words borrowed from other (mainly European) languages (gairaigo 外来語). The distinction can be summarised as follows:

(1) Categories of Japanese words according to their origin ( $g o s h u$ 語種):

a. domestic words: wago 和語

b. borrowed words: kango 漢語 (of Chinese origin), gairaigo 外来語 (from other languages)

This paper is only concerned with words of foreign origin borrowed from languages other than Chinese (gairaigo). Hereafter, the term loanword shall only be used in this restricted meaning, as a term for words of foreign, but not Chinese origin. If compared with research on domestic words and words of Chinese origin, research on loanwords (gairaigo) is lagging far behind, as has been noticed in previous research (e.g. Ishino 1996, Kim 2011). There are only very few analyses of the meaning of loanwords and the difference in usage with respect to domestic words and words of Chinese origin, while the grammatical behaviour of loanwords - how loanwords are used within sentences - has hardly been studied at all.

On the other hand, research on Japanese language teaching (e.g. Sawada, 1993; Nakayama et al., 2008) has often stressed that loanwords (alternatively termed also 
katakana-words) pose considerable difficulties to foreign learners of Japanese and that their teaching and explanation has not been adequately addressed. In fact, loanwords which appear in textbooks of Japanese as a foreign language are usually only introduced with an example and a one-word gloss (a synonym) to indicate meaning, while their grammatical behaviour is generally not discussed at all.

Loanwords share some general grammatical properties with words borrowed from Chinese, namely, that they can be used as nouns (in their most basic form), or as verbs (if the light-verb suru is appended), or as adjectives (with the addition of the copula $d a$ or of the particle $n a$ ). However, these rules cannot be applied to all loanwords, as can be seen in (2), and learners need to check and memorise the grammatical and syntactical properties of each word individually. For each loanword, they need to check whether it can be used as a verb, whether such a verb is transitive or intransitive and in what syntactical pattern it can be used, etc. Consider the loanwords listed in (2): while words in list (2) a. can be used as verbs with the addition of suru, words in list (2) b. cannot.

(2) a. adobaisu-suru ("to advise"), imeeji-suru ("to imagine"), katto-suru ("to cut"), rirakkusu-suru ("to relax");

b. *kureemu-suru (*“to do claim/complaint"), *doriimu-suru (*“to do dream"), *shotto-suru (*"to do shot"), *panikku-suru (*"to do panic")

However, in existing dictionaries of verb patterns such as Koizumi et al. (1989) or collocation dictionaries such as Himeno (2004), which are used by teachers and learners of Japanese as a foreign language, loanword verbs such as those given in (2) are not included. Descriptive research on loanword verbs, adjectives and nouns, especially research examining their syntactic behaviour, is therefore needed both from a general linguistic point of view, in order to have a better description of this part of the Japanese lexicon, as well as from an applied point of view, to obtain basic data from which applied linguistic research such as lexicography or Japanese language teaching could greatly profit.

The final aim of such research on the grammatical behaviour of loanwords is to accumulate accurate descriptions of individual loanwords, which are eventually to be edited into a dictionary of loanword grammatical patterns. The present paper makes a first step in this direction by presenting a case study of the verb katto-suru, analysing its semantic and grammatical characteristics which can be extracted from a corpus, and showing how such information can be ordered and presented to learners of Japanese.

\section{Loanword suru-verbs in BCCWJ}

The following analysis is based on data from the 2009 monitor data version of the Balanced Corpus of Contemporary Written Japanese (hereafter abbreviated to BCCWJ). BCCWJ is a large-scale corpus consisting of texts from different media, including books, white papers, the online Q\&A web-site Yahoo!Chiebukuro and 
Minutes of the Japanese Diet (parliamentary proceedings), amounting to ca. 45 million words.

A corpus-wide search for loanword suru-verbs yielded 18,094 tokens corresponding to 1,421 types. ${ }^{1}$

Table 1 shows the list of loanword suru-verbs with the first 30 frequency ranks, alongside their description in three dictionaries and two other works: the largest existing dictionary of Japanese loanwords, the Concise katakana-go jiten (4th ed., with ca. 48,000 lemmas), two medium-size general Japanese language dictionaries, Meikyō kokugo jiten (ca. 70,000 lemmas) and Iwanami kokugo jiten (7th ed., ca. 65,000 words), a textbook of Japanese loanwords (Sasaki, 2001), and a research paper on basic loanwords in the context of teaching Japanese as a foreign language (Sawada, 1993).

Table 1: The 30 most common loanword suru-verbs in BCCWJ and their description in five reference works ${ }^{2}$

\begin{tabular}{|c|c|c|c|c|c|c|c|c|}
\hline$\dot{z}$ & 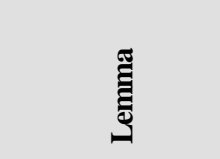 & ש气 & 흘 & 흘 & 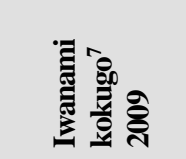 & 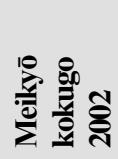 & 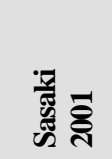 & 密 \\
\hline 1 & クリック & kurikku & 1,385 & $\Delta$ & $\circ$ (tr.) & $\circ$ (tr.) & $x$ & $x$ \\
\hline 2 & チェック & chekku & 815 & ○ & $\circ$ (tr. \& intr.) & $\circ$ (tr.) & $\circ$ (tr.) & o \\
\hline 3 & スタート & sutaato & 553 & ○ & $\circ$ (intr.) & $\circ$ (intr.) & ○ (intr.) & ० \\
\hline 4 & インストール & insutooru & 338 & 0 & $\circ$ (tr.) & $\circ$ (tr.) & $x$ & $\times$ \\
\hline 5 & コピー & kopii & 334 & $\circ$ & $\circ$ (tr.) & $\circ$ (tr.) & $\circ($ tr. $)$ & $\circ$ \\
\hline 6 & コントロール & kontorooru & 313 & $\circ$ & $\circ$ (tr.) & $\circ$ (tr.) & $\circ$ (tr.) & $\circ$ \\
\hline 7 & メール & meeru & 304 & $\Delta$ & $\Delta$ & $\Delta$ & $x$ & $\times$ \\
\hline 8 & カバー & kabaa & 284 & ○ & $\circ$ (tr.) & $\circ$ (tr.) & $\circ($ tr. $)$ & $\circ$ \\
\hline 9 & クリア & kuria & 261 & 0 & $\circ$ (tr.) & $\circ$ (tr.) & $\circ$ (tr.) & 0 \\
\hline
\end{tabular}

\footnotetext{
${ }^{1}$ The search was performed using the whole-text search system package Himawari, which is included in the BCCWJ monitor data set, searching with the condition "katakana + suru in all inflected forms", which does not include "katakana $+r u$ " nor "katakana + dekiru". Types were counted according to the following criteria. (1) Orthographic variants such as $b a / v a$ (バ/ヴア) or variants with long/short vowels are counted as separate types. (2) Compound words such as katto\&peesuto-suru or pasukatto-suru are counted as individual, separate types. (3) Words of mixed origin, such as dotakyan-suru are also included. (4) Words which are generally accompanied by the particle wo when used with the verb suru (such as sakkaa-suru) are also included.

${ }^{2}$ In Table 1, the symbol $\circ$ indicates that the reference work contains a description of the word's usage as a suru-verb, possibly including the distinction transitive (tr.) /intransitive (intr.); the symbol $\Delta$ indicates that the reference work contains the word in question, but only in a usage other than as a suru-verb; the symbol $\times$ indicates that the word is not listed as a lemma.
} 


\begin{tabular}{|c|c|c|c|c|c|c|c|c|}
\hline$\dot{\mathbf{z}}$ & 袍 & 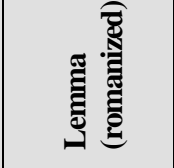 & 它 & 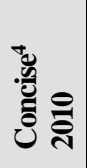 & 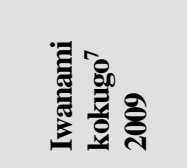 & 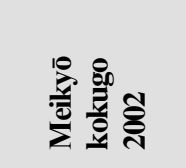 & 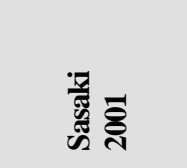 & हึ \\
\hline 10 & カット & katto & 252 & $\circ$ & $\circ$ (tr.) & $\circ($ tr. $)$ & $\circ($ tr. $)$ & $\circ$ \\
\hline 11 & イメージ & imeeji & 243 & $\circ$ & $\circ$ (tr.) & $\circ$ (tr.) & $\circ$ (tr.) & ○ \\
\hline 12 & ダウンロード & daunroodo & 240 & $\Delta$ & $\circ$ (tr.) & $\circ$ (tr.) & $x$ & $x$ \\
\hline 13 & セット & setto & 220 & ○ & $\circ$ (tr.) & $\circ$ (tr.) & $\circ$ (tr.) & $\circ$ \\
\hline 14 & プレゼント & purezento & 206 & $\circ$ & $\circ$ (tr.) & $\circ$ (tr.) & $\circ$ (tr.) & $\circ$ \\
\hline 15 & リード & riido & 206 & $\circ$ & $\circ$ (tr. \& intr.) & $\circ$ (tr.) & $\circ$ (tr. \& intr.) & ० \\
\hline 16 & アピール & apiiru & 205 & $\circ$ & $\circ($ tr. \& intr.) & $\circ($ tr. \& intr. $)$ & $\circ$ (tr.) & o \\
\hline 17 & キス & kisu & 202 & $\circ$ & $\circ$ (intr.) & $\circ$ (intr.) & $\times$ & o \\
\hline 18 & チャレンジ & charenji & 197 & $\circ$ & O (tr. \& intr.) & o (intr.) & $\circ$ (intr.) & ० \\
\hline 19 & アクセス & akusesu & 194 & $\Delta$ & ○ (intr.) & o (intr.) & $\times$ & $\times$ \\
\hline 20 & ヒット & hitto & 174 & $\circ$ & ○ (intr.) & $\circ$ (intr.) & o (intr.) & ० \\
\hline 21 & リラックス & rirakkusu & 169 & $\circ$ & ○ (intr.) & ○ (intr.) & ○ (intr.) & o \\
\hline 22 & アップ & арри & 167 & $\circ$ & $\circ$ (tr. \& intr.) & $\circ$ (tr. \& intr.) & O (tr. \& intr.) & ० \\
\hline 23 & キャンセル & kyanseru & 167 & $\circ$ & $\circ($ tr.) & $\circ($ tr. $)$ & $\circ($ tr. $)$ & $x$ \\
\hline 24 & サポート & sapooto & 164 & ○ & $\circ$ (tr.) & $\circ$ (tr.) & $\circ$ (tr.) & $\circ$ \\
\hline 25 & ノック & nokku & 150 & ○ & $\circ$ (tr.) & o (intr.) & $\times$ & $\circ$ \\
\hline 26 & $x モ$ & meто & 142 & ○ & $\circ($ tr. $)$ & $\circ$ (tr.) & $\circ$ (tr.) & $\circ$ \\
\hline 27 & エスカレート & esukareeto & 134 & ○ & $\circ$ (intr.) & $\circ$ (intr.) & $\circ$ (intr.) & $\circ$ \\
\hline 28 & デザイン & dezain & 132 & $\circ$ & $\circ$ (tr.) & $\circ$ (tr.) & $x$ & ० \\
\hline 29 & リンク & rinku & 126 & o & $\circ$ (tr.) & $\circ($ tr.) & $\circ$ (tr.) & $x$ \\
\hline 30 & シフト & shifuto & 123 & $\circ$ & $\circ$ (intr.) & $\circ$ (intr.) & $x$ & ० \\
\hline 31 & デビュー & debуии & 123 & ○ & $\circ$ (intr.) & $\circ$ (intr.) & $x$ & ○ \\
\hline 32 & バックアップ & bakkиарри & 123 & $\circ$ & $\circ$ (tr.) & $\circ$ (tr.) & $\circ$ (tr.) & ○ \\
\hline
\end{tabular}

The 20 most frequent verbs were the following.

(3) kurikku-suru ("to click"), chekku-suru ("to check"), sutaato-suru ("to start"), insutooru-suru ("to install"), kopii-suru ("to copy"), kontorooru-suru ("to control"), meeru-suru ("to mail"), kabaa-suru ("to cover"), kuria-suru ("to clear"), katto-suru ("to cut"), imeeji-suru ("to imagine"), daunroodo-suru ("to download"), setto-suru ("to set"), purezento-suru ("to give as a present"), riidosuru ("to lead"), apiiru-suru ("to appeal"), kisu-suru ("to kiss"), charenji-suru ("to challenge"), akusesu-suru ("to access"), hitto-suru ("to hit") 
Among these, the underlined verbs are mostly used as technical terms related to computers. The reason for the verb kurikku-suru to have such a prominent frequency is that this word is used repeatedly in explanations of operation instructions in software user manuals. Approximately 900 of the examples found come from such manuals. Similarly, approximately $90 \%$ of the occurrences of insutooru-suru, meeru-suru and daunroodo-suru come from the site Yahoo!'Chiebukuro.

If we compare the list of the 20 most frequent loanwords in (3) and the list of "basic loanwords" proposed by Sawada (1993), we find that only the underlined words in (3) are not included in Sawada's list. Leaving aside computer terminology, which is highly susceptible to changes in time, we therefore find that most basic loanwords were found in this corpus search.

In the following section, the verb katto-suru is analysed in detail. The verb kattosuru was chosen because of its polysemy and because it is a general verb, and its use is not restricted to one particular subject area.

\section{A case study: analysis of the verb katto-suru}

Subsection 4.1 presents a semantic analysis of the verb katto-suru, based on examples from the BCCWJ, while subsection 4.2 offers an analysis of the sentencefinal forms and other elements co-occurring with this verb.

\subsection{Semantic characteristics}

The loanword katto is derived from the English word cut. The loanword dictionary Concise katakana-go jiten (4th ed.) defines it as follows. The definition given below is partly abridged.

(4) カット [cut] 〜する

1. 切ること, 削除, 省略。

2. 洋裁の裁断。

3.『テニス・卓球など】打球に後退回転を与えること。

4.【バスケットなど】相手のボールを横合いから奪い取ること。

5.【野球】野手が他の野手の送球を途中で捕球すること。

6. 『トランプ』札を切ること。親が札を切り混ぜた後, 子がその札を 2 分し, いかさまのないことを確認するもの。

7. 小型のさし絵, 写真。

8. 映画やテレビで, ショットを編集作業により, 適当な長さに 切ったもの。また, 監督や演出家が, 1 つのショットの撮影を終 える時にする合図。

9.【美容】髪を切り，形を整えること。

10. 『ダンス』上げた足をもう一方の足にたたきつけるようにして， すばやく立ち足を変えるもの。基本ステップの 1 。

11. 宝石を多面体に削ること。 
This could be translated as follows.

(4) katto [cut] suru

1. cutting, deletion, omission.

2. cutting cloth in dressmaking.

3. \{tennis, table-tennis etc. $\}$ giving a backwards spin to a batted ball.

4. \{basketball etc. \} snatching the opponent's ball from aside.

5. \{baseball $\}$ a fielder's getting another fielder's ball.

6. \{card games \} cutting the cards; the non-dealer's splitting the pack of cards into two parts after the dealer has shuffled the cards, to avoid cheating.

7. small illustration, photograph.

8. in film or television, a take that is cut to appropriate length during editing; or, the signal given by the film director or an actor at the end of a take.

9. \{hairdressing \} cutting and arranging hair.

10. \{dance \} quick change of supporting foot by flinging the moving foot onto the other foot; one of the basic steps.

11. shaping a rough gemstone into a faceted shape.

This is a very detailed description, including various uses of the word as a technical term. However, there is no explanation regarding which of these meanings is commonly used, nor any indication as to whether the word can be used as a verb (in the form katto-suru) in all the meanings listed.

To investigate these points, we collected examples of katto-suru from BCCWJ and ordered them according to their meaning. The result of this analysis is presented in Table 2, including frequency information.

Table 2: Semantic analysis of katto-suru examples

\begin{tabular}{|c|c|c|c|}
\hline \multicolumn{2}{|l|}{ Meaning } & \multicolumn{2}{|c|}{$\begin{array}{c}\text { No. of } \\
\text { examples }\end{array}$} \\
\hline \multirow{2}{*}{ [1] cut } & $\begin{array}{l}\text { [food] wo katto suru - to reduce into small pieces, to divide } \\
\text { [peel/rind/husk] wo katto suru - to peel, to pare, to skin }\end{array}$ & 46 & \multirow{2}{*}{98} \\
\hline & $\begin{array}{l}\text { [long thin things] wo katto suru - to shorten } \\
\text { [thin things] wo katto suru - to make smaller }\end{array}$ & 52 & \\
\hline [2] cut hair & [hair] wo katto suru - to cut and arrange & 33 & 33 \\
\hline \multirow{2}{*}{$\begin{array}{l}{[3] \text { cut down, }} \\
\text { reduce }\end{array}$} & [images/text/items] wo katto suru - to delete, to abridge & 45 & \multirow{2}{*}{103} \\
\hline & [money/quantity] wo katto suru - to reduce, to cut down & 58 & \\
\hline \multirow{2}{*}{$\begin{array}{l}\text { [4] cut off, } \\
\text { block, obstruct }\end{array}$} & [ultraviolet rays/light] wo katto suru - to cut off, to block & 12 & \multirow{2}{*}{14} \\
\hline & [a ball/ a pass] wo katto suru - to take, to intercept & 2 & \\
\hline \multicolumn{2}{|c|}{ [5] other meanings } & 4 & 4 \\
\hline & Total: & \multicolumn{2}{|r|}{252} \\
\hline
\end{tabular}


Senses [1] to [4] were created on the basis of corpus examples, but also taking into account definitions in existing dictionaries. The common basic meaning of katto-suru could be described as "to make a cut into something, making it into another (smaller) shape".

Examples of usage for each sense described in Table 2 are given below. The codes in brackets refer to the sample ID in BCCWJ.

(5) sense [1]: to reduce into small pieces, to divide, to make shorter, smaller

a. 野菜なども使う分だけ皮をむいて使う大きさにカットし、密閉容器に 入れていくといい。

Yasai nado mo tsukau bun dake kawa o muite tsukau ookisa ni katto shi, mippei youki ni irete iku to ii.

"You should also peel just the vegetables you will need, cut them to the size you need and put them into airtight containers."

(PB25_00290)

b．皮をナイフで薄くカットします。果肉は食用とします。

Kawa o naifu de usuku katto shimasu. Kaniku wa shokuyou to shimasu.

"Thinly cut off the husk. The fruit pulp will be used for dish preparation."

(LBm5_00033)

c. 編み終わりは、ひもの余分をカットし、内側にボンドでとめる。 Amiowari wa, himo no yobun o katto shi, uchigawa ni bondo de tomeru. "When the knitting is finished, cut off the excess thread and paste it inside."

(LBs5_00032)

d. 先ほど受験用写真をきれいにカットするコッを質問した者です。 Sakihodo juken'you shashin o kirei ni katto suru kotsu o shitsumon shita mono desu.

"I am the one who just asked about tricks for cleanly cutting/trimming pictures for exams."

(OC10_00401)

(6) sense [2]: to cut and arrange hair

避暑地のお嬢さんらしく、帽子に隠れた髪は、学校にいる時より短く カットされている。

Hishochi no ojouchan rashiku, boushi ni kakureta kami wa, gakkou ni iru toki yori mijikaku katto sarete iru.

"Her hair, tucked away under her hat, is cut shorter than when she is at school, as would befit a young lady in a summer resort."

(LBr9_00274)

(7) sense [3]: to delete, to abridge, to reduce, to cut down

a. 読んでみると、議事録からは『あ一』とか『う一』はカットされてい る。

Yonde miru to, gijiroku kara wa "aa" to ka "uu” wa katto sarete iru.

"On reading it, one finds that aahs and uhms have been cut out of the minutes."

(PB26_00141) 
b. 公務員の数は半分になり、給与は 3 割カット、退職金は半減、または 全額カットされる。

Koumuin no kazu wa hanbun ni nari, kyuuyo wa sanwari katto, taishokukin wa hangen, mata wa zengaku katto sareru.

"The number of public servants is halved, allowances reduced by $30 \%$, retirement money reduced by half or completely abolished."

(PB53_00657)

(8) sense [4]: to cut off, to block, to intercept

a. 前述の通り遮光板で上方の光が綺麗にカットされるため、マルチリフ レクターより暗く感じる。

Zenjutsu no toori, shakouban de jouhou no hikari ga kirei ni katto sareru tame, maruchirefurekutaa yori kuraku kanjiru.

"As stated earlier, the light above is completely cut off by the gobo, so that one feels it darker than with a multi-reflector."

(OC06_03304)

b. ディフェンスしてて相手の蹴ったボールを胸でカットした、とかなら まだしも。

Difensu shite te aite no ketta booru o mune de katto shita, toka nara madashimo.

"I could get it if he had got the other's ball with his chest for defence."

(OC14_03488)

(9) other uses:

a. 〈斜めに切るように打つ> バレーボールのボールなどを打つときに ボールの下部を手のひらでカットするようにするのと、

[to strike with a diagonal slash] Bareebooru no booru nado o utsu toki ni booru no kabu o tenohira de katto suru youni suru no to,

"Striking the lower part of the ball with one's palm of the hand in volleyball and the like, and..."

(PB4n_00054)

b. 〈解除する> 中古車で、リミッターがカットされている車は売られ ているものなのでしょうか?

[to unlock, to deactivate] Chuukosha de, rimittaa ga katto sareteiru kuruma wa urareteiru mono na no deshouka?

"In the case of used cars, are cars with deactivated speed limiters being sold?"

(OC06_00923)

From a semantic point of view, sense [2] "to cut hair" could be merged into sense [1], since it coincides with the sense "to shorten long thin things". However, since examples categorised as sense [2] contain mediative expressions (expressions of semantic indirectness), as will be explained later, these examples were put in a separate sense.

Sense [3] is generally presented in dictionaries as "to delete/abridge a part of a text or sum of money", but in fact it may express the deletion of something in its completeness, as it can collocate with expressions such as zenbu (全部 “all”) or 
zengaku (全額 “the whole sum”) as in example (7b). However, these cases may also be interpreted as "considering a larger unit, making the larger unit smaller".

It should be noted that most dictionaries present the use of katto-suru as a specialised term in sports, such as senses 3. and 4. in the dictionary description quoted at (4), but that examples of this use such as (8b) and (9a) were actually very rare in BCCWJ.

\subsection{Syntactical characteristics}

This section explores the syntactical characteristics of the verb katto-suru, beginning with co-occurrence patterns, for each of the senses presented in 4.1.

\subsubsection{Co-occurrence patterns}

Let us first consider the case particles and adverbs occurring in sentences where the predicate is katto-suru. Table 3 presents data for all patterns occurring in at least 5 examples.

Table 3: Co-occurrence patterns of katto-suru

\begin{tabular}{|c|c|c|c|c|c|c|c|}
\hline \multirow[b]{2}{*}{ Sense } & \multirow{2}{*}{$\begin{array}{c}\text { No. of } \\
\text { examples }\end{array}$} & \multicolumn{4}{|c|}{ Case particles } & \multicolumn{2}{|c|}{ Adverbial expressions } \\
\hline & & $\begin{array}{c}o \\
\text { (object) }\end{array}$ & $\begin{array}{c}d e \\
\text { (instr.) }\end{array}$ & $\begin{array}{c}d e \\
\text { (location) }\end{array}$ & $\begin{array}{c}\text { kara } \\
\text { (source) }\end{array}$ & $\begin{array}{c}\text { Adverbs of } \\
\text { result }\end{array}$ & $\begin{array}{c}\text { Adverbs of } \\
\text { quantity }\end{array}$ \\
\hline [1] cut & 98 & 66 & 9 & & 1 & 32 & 8 \\
\hline [2] cut hair & 33 & 11 & 3 & 6 & & 11 & \\
\hline [3] reduce & 103 & 52 & & & 5 & 4 & 16 \\
\hline [4] block & 14 & 12 & 2 & & & & \\
\hline [5] other & 4 & 2 & & & & & \\
\hline Total & 252 & 143 & 14 & 6 & 6 & 47 & 24 \\
\hline
\end{tabular}

The direct object of the transitive verb katto-suru marked by particle $o$, including cases where the object is topicalised and marked by particle wa, appears in the same sentence in 143 of 252 cases $(56.7 \%)$. There are 54 further cases when the patient, which is usually marked by particle $o$, appears as the subject of a passive sentence marked by particle $g a$, and 10 cases where the patient is the head of a noun-modifying clause and therefore not accompanied by any particle. An accurate count of the examples where the patient (usually accompanied by particle $o$ ) is really absent therefore yields 45 examples altogether (17.9\%). Since 20 of these are examples of sense [2], we can conclude that one of the characteristics of sense [2] is that it tends not to co-occur with the verb's direct object, although it is sometimes difficult to decide whether an example such as (10) should be considered to be a case of transitive sentence where the object kami o (髮を "hair $o$ ") is omitted, or a case of intransitive 
sentence. In this analysis, such sentences were considered to be cases of transitive sentences.

(10) 私はいつも美容院でカットしている。

Watashi wa itsumo biyouin de katto-shite iru.

"I always have [my hair] cut at the hairdressers." / "I also have a cut at the hairdressers.")

Other particles that characteristically co-occur are instrumental particle de with sense [1] (e.g. hasami de katto-suru "cut with scissors"), locative particle de with sense [2] (e.g. biyouin de katto-suru "to cut / have a haircut at the hairdressers"), source particle kara with sense [3] (e.g. chingin kara katto-suru "to cut from wages").

If we now consider adverbial expressions, we find that sense [1] and [2] are often accompanied by adverbs which express the result of cutting, such as "...o mijikaku ("short") / hitokuchidai ni ("to a mouthful") / suki na katachi ni ("to one's preferred shape") katto-suru", while sense [3] is often accompanied by adverbs of quantity or degree, such as "... o sukoshi ("a little") / ichibu ("in part") / zengaku ("completely, for the whole sum") katto-suru".

On the basis of this analysis of co-occurrences, table 4 summarises typical patterns for each sense, taking into account patterns which occurred in approximately $10 \%$ or more examples.

Table 4: Senses and patterns of katto-suru

\begin{tabular}{|c|c|c|c|}
\hline \multicolumn{2}{|r|}{ Sense } & Arguments & Patterns \\
\hline \multirow{2}{*}{ [1] cut } & $\begin{array}{l}\text { to process / peel / } \\
\text { separate }\end{array}$ & $\begin{array}{l}{[\text { food }] o} \\
([\text { tool }] d e)\end{array}$ & \multirow{2}{*}{$\begin{array}{l}o \text { case } \\
(+ \text { instrumental } d e \text { case }) \\
(+ \text { expression of result })\end{array}$} \\
\hline & to shorten / make smaller & $\begin{array}{l}\text { [thin and long / thin object }] \\
\text { ([tool] } d e)\end{array}$ & \\
\hline [2] cut hair & to cut and arrange hair & $\begin{array}{l}([\text { hair }] o) \\
([\text { place }] d e)\end{array}$ & $\begin{array}{l}(o \text { case }) \\
(+ \text { locative de case }) \\
(+ \text { expression of result })\end{array}$ \\
\hline \multirow{2}{*}{ [3] reduce } & to delete / abridge & [images / text / items] $o$ & \multirow{2}{*}{$\begin{array}{l}o \text { case } \\
(+ \text { expression of quantity / } \\
\text { degree })\end{array}$} \\
\hline & to reduce the quantity & [money / quantity] $o$ & \\
\hline \multirow{2}{*}{ [4] block } & block, obstruct & $\begin{array}{l}\text { [ultraviolet rays / light] } o \\
\text { ([tool] de) }\end{array}$ & \multirow{2}{*}{$\begin{array}{l}o \text { case } \\
(+ \text { instrumental } d e \text { case })\end{array}$} \\
\hline & take, intercept & $\begin{array}{l}\text { [a ball / a pass] } o \\
\text { ([bodypart] } d e)\end{array}$ & \\
\hline
\end{tabular}

As could be seen above, by analysing corpus data it is possible to present detailed information regarding cases, arguments and adverbs which tend to co-occur with a particular verb, and the semantic category of nouns which tend to appear in these 
arguments. In the case of katto-suru, it was shown that all senses appear in transitive uses of the verb, but that each sense appears in its own particular pattern.

\subsubsection{Sentence-final forms}

Let us now see the characteristic sentence-final forms such as voice markers and auxiliary verbs which appear after the verb katto-suru. Table 5 presents forms which have appeared in at least 5 examples.

Table 5: Sentence-final forms of katto-suru

\begin{tabular}{|l|c|c|c|c|c|c|c||}
\hline \hline Sense & $\begin{array}{c}\text { No. of } \\
\text { examples }\end{array}$ & $\begin{array}{c}\text {-rare- } \\
\text { (passive) }\end{array}$ & $\begin{array}{c}\text {-te iru } \\
\text { (progressive/ } \\
\text { resultative/ } \\
\text { havitual) }\end{array}$ & $\begin{array}{c}\text {-te shimau } \\
\text { (perfect) }\end{array}$ & $\begin{array}{c}\text {-te morau } \\
\text { (benefactive) }\end{array}$ & $\begin{array}{c}\text {-te iku (future } \\
\text { continuation) }\end{array}$ & $\begin{array}{c}\text {-you } \\
\text { (volitive) }\end{array}$ \\
\hline \hline [1] cut & 98 & 9 & 4 & 1 & & 2 & \\
\hline [2] cut hair & 33 & 2 & 8 & & 6 & 1 & \\
\hline$[3]$ reduce & 103 & 39 & 16 & 6 & 1 & 4 & 5 \\
\hline$[4]$ block & 14 & 2 & & 1 & & & \\
\hline [5] other & 4 & 2 & 2 & & & & $\mathbf{7}$ \\
\hline Total & $\mathbf{2 5 2}$ & $\mathbf{5 4}$ & $\mathbf{3 0}$ & $\mathbf{8}$ & $\mathbf{7}$ & $\mathbf{7}$ & $\mathbf{5}$ \\
\hline
\end{tabular}

A very conspicuous point is that sense [3] tends to occur in the passive form much more than other senses $(72.2 \%$ of all passive sentences pertain to this sense). This tendency reflects the fact that the situation of "reducing / cutting down surplus parts of a text, image or sum of money" is depicted from the point of view of the (possibly unwitting) receiver more often than the other senses. This is also corroborated by the fact that as much as 6 examples of -te shimau, an auxiliary verb expressing regret, are used in this sense in the passive form. Conversely, the volitive form -you, which is used when viewing the act from the opposite point of view, such as the administration or management, is used very rarely and almost exclusively in parliament proceedings and economic texts.

Sense [2], on the other hand, often occurs with benefactive verbs (-te morau "receive" or -te kureru "give (to me)"), expressing gratitude for the received action. Katto-suru used in sense [2] exhibits the characteristic of semantic indirectness (mediativeness) (kaizaisei 介在性, Sato, 2005), in the sense that it can be used in examples such as (10) even when it was a hairdresser or someone else (and not the subject of the sentence) who actually cut the hair, at the subject's request. The syntactic construction with an auxiliary benefactive verb could therefore be considered as a syntactic reference to the agent who acted upon request.

If we now consider the form -te iru, we find as many as 22 examples where the form expresses the resulting state of an action (16 of these are in the passive form), 
while most remaining examples refer to sense [2]: 6 examples of repetitive action / habit, 1 example of progressing action. The tendency of sense [2] to appear in forms expressing repetition can be seen as stemming from the fact that the action of "cutting one's hair" is something done habitually.

Finally, all examples of the form -te $i k u$, regardless of the verb sense, express gradual development or progression of the action described and do not exhibit any particularity regarding sense.

\subsection{Analysis}

As could be seen in the above analysis, usage examples of katto-suru taken from the corpus BCCWJ can show not only the characteristics of nouns which can typically co-occur as objects, but also the characteristics of co-occurring expressions and predicate forms which are typical for each sense.

For example, with regard to sense [2] "cut one's hair", the following syntactical characteristics have been observed.

(11) a. There are cases in which the object with particle o is not expressed, since the object "hair" is taken for granted.

b. There is sometimes an argument with locative case particle $d e$, such as "biyouin de" ("at the hairdresser's").

c. The verb is often accompanied by expressions of result, such as "mijikaku" ("short").

d. The verb is often in the form -te iru, expressing repetitive action or habit.

e. It can appear in sentences expressing semantic indirectness (mediativeness), in which reference to the agent is made by means of auxiliary benefactive verbs.

The fact that we can observe such an equivalence between the senses of a verb and its syntactical characteristics means that we can predict - to a certain extent - the meaning and subsense of a word from the form of its sentence, and vice versa the form of a sentence from the meaning (or subsense) of a word.

In the context of teaching Japanese as a foreign language, providing learners with a description of a verb which includes not only its lexical meaning, but also its patterns of usage as presented in table 4, would help them in receptive and productive tasks, since it would provide them with the information they need to tell, for example, which sense of katto-suru is meant in the sentence they read, judging from the co-occurring words and patterns, or to predict, for example, which words and patterns can be used with katto-suru when they want to use this verb in a particular sense. 


\section{Conclusion}

The results of the case study presented in this paper indicate the importance of analysing loanwords from a grammatical perspective, investigating their behaviour within sentences and not only their meaning.

Judging from the many differences in the description of loanwords in monolingual Japanese dictionaries, as presented in Table 1, it is clear that much is still unknown regarding loanwords in contemporary Japanese. The first task that awaits us is to build up a comprehensive description of basic loanwords, on the basis of corpus data. As has been shown in the present paper, the results of such a description would be very useful to the teaching of Japanese as a foreign language.

At the same time, while preparing detailed analyses of individual words, a descriptive lexicographical framework aimed at foreign learners needs to be developed, indicating what information needs to be included in a description of grammatical patterns. Moreover, even a corpus of the size of BCCWJ may sometimes not offer enough examples for fine-grained distinctions of meaning. The solution of this problem is another task that awaits us.

\section{References}

Himeno, M. (2004). Kenkyūsha Nihongo Hyōgen Katsuyō Jiten. Kenkyūsha.

Ishino, H. (1996). Jiten ni okeru Gairaigo no Gogi Kijutsu. In Gengogakurin 1995-1996. Tokyo: Sanseidō. 273-286.

Kim, E. (2011). 20-seiki Kōhan no Shinbun Goi ni okeru Gairaigo no Kihongoka. (Shift of the Loanwords to Basic Words in the Japanese Newspaper Vocabulary in the Second Half of the 20th Century.) Handai Nihongo Kenkyu, Monograph 3. Toyonaka: Osaka University.

Kitahara, Y. (2002). Meikyō Kokugo Jiten. Tokyo: Taisyūkan.

Koizumi, T., Funaki, M., Honda, K. Nitta,Y. \& Tsukamoto, H. (1989). Nihongo Kihon Dōshi Yōhō Jiten. Tokyo: Taisyūkan.

Nakayama, E., Jinnouchi, M., Kiryu, R., \& Miyake, N. (2008). Nihongo kyōiku ni okeru "Katakanago Kyōiku" no Atsukawarekata. (Teaching Japanese as a Foreign Language: Katakana and its Implementation in the Syllabus.) Nihongo Kyōiku, 138, 83-91.

Nishio, M., Iwabuchi, E., \& Mizutani, S. (2009). Iwanami Kokugo Jiten. 7th ed. Tokyo: Iwanami Shoten.

Sanseidō Henshūjo. (2010) Concise Katakanago Jiten. 4th ed. Tokyo: Sanseidō.

Sasaki, M. (2001). Yoku Tsukau Katakanago. Tokyo: Alc.

Sato, T. (2005). Jidōshi-bun to Tadōshi-bun no Imiron. Tokyo: Kasamashoin.

Sawada, T. (1993). Nihongo Kyōiku no tameno Kihon Gairaigo ni tsuite. (Loanwords Usage in Japanese: The Fundamental Points for the Japanese Language Teaching.) Bulletin of Nara University of Education. Cultural and Social Science, 42(1), 225-239. 